\title{
New diamond composite tools and their impact on AISI 4140 alloy steel surface after slide burnishing
}

\author{
Nowe diamentowe narzędzia kompozytowe \\ i ich wpływ na powierzchnię stali stopowej AISI 4140 \\ po nagniataniu ślizgowym
}

\author{
MAGDALENA SZUTKOWSKA \\ DANIEL TOBOKA \\ LUCYNA JAWORSKA \\ MARCIN ROZMUS*
}

DOI: https://doi.org/10.17814/mechanik.2019.10.78
Working parts of slide burnishing tools were made from two new diamond composites with ceramic bonding: $\mathrm{MAX} \mathrm{Ti}_{3} \mathrm{GeC}_{2}$ and $\mathrm{TiB}_{2 \text { nano }}$ phases, respectively. Microstructure and micro composition were analyzed by scanning and transmission electron microscopy and X-ray diffraction. Vickers hardness HV1 values were 36 and $46 \mathrm{GPa}$, Young's moduli 490 and $560 \mathrm{GPa}$, tensile strengths 400 and $560 \mathrm{MPa}$, fracture toughness 8.4 and $11.0 \mathrm{MPa} \cdot \mathrm{m}^{1 / 2}$ and friction coefficient values 0.63 and 0.56 , respectively for the composites with $M A X \mathrm{Ti}_{3} \mathrm{GeC}_{2}$ and $\mathrm{TiB}_{2 \text { nano }}$ phases. The tools were tested by slide burnishing on previously turned AISI $\mathbf{4 1 4 0}$ alloy steel bar. Improvement in the surface geometric structure was demonstrated for both materials, more so in the case of $\mathrm{TiB}_{2 \text { nano }}$ phase, as compared to burnishing by composites with $\mathrm{MAX} \mathrm{Ti}_{3} \mathrm{GeC}_{2}$ phase.

KEYWORDS: diamond composite, $\mathrm{TiB}_{2 \text { nano }}$ phase, MAX phase, HP-HT sintering, slide burnishing, surface roughness

Części robocze narzędzi do nagniatania ślizgowego zostały wykonane $z$ dwóch nowych kompozytów diamentowych ze spoiwem ceramicznym, odpowiednio z fazą $M A X \mathrm{Ti}_{3} \mathrm{GeC}_{2}$

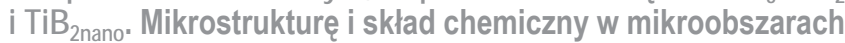
analizowano za pomocą skaningowej i transmisyjnej mikroskopii elektronowej oraz dyfrakcji rentgenowskiej. Parametry kompozytów z fazami MAX $\mathrm{Ti}_{3} \mathrm{GeC}_{2}$ i $\mathrm{TiB}_{2 \text { nano }}$ wynosiły odpowiednio: twardość Vickersa HV1 - 36 i 46 GPa, moduł Younga - 490 i $560 \mathrm{GPa}$, wytrzymałość na ściskanie promieniowe - 400 i $560 \mathrm{MPa}$, odporność na pękanie - 8,4 i 11,0 MPa - $\mathrm{m}^{1 / 2}$, współczynnik tarcia - 0,63 i 0,56. Narzędzia testowano poprzez nagniatanie ślizgowe na uprzednio toczonym pręcie ze stali stopowej AISI 4140. Wykazano poprawę struktury geometrycznej powierzchni dla obu materiałów - większą dla końcówki z fazą $\mathrm{TiB}_{2 \text { nano }} \mathrm{w}$ porównaniu do nagniatania końcówką $\mathbf{z}$ fazą $\mathrm{MAX} \mathrm{Ti}_{3} \mathrm{GeC}_{2}$

SŁOWA KLUCZOWE: kompozyt diamentowy, faza $\mathrm{TiB}_{2 \text { nano, }}$ faza MAX, spiekanie HP-HT, nagniatanie ślizgowe, chropowatość powierzchni

\section{Introduction}

In traditional manufacturing processes the finishing operation of machine parts is often grinding - resulting in hardness after heat treatment higher than $45 \mathrm{HRC}$ or even $60 \mathrm{HRC}$. For several decades in many industries, e.g. automotive, bearing, and dies manufacturing, processes of grinding have been gradually replaced by so called "hard machining" (HM) [1]. Not always, however, HM meets the requirements for the expected surface quality. The method to overcome these technological barriers is burnishing, which is applied both to the turned and milled surfaces [1]. Among the different methods of finishing, the main distinguishing feature of burnishing is the use of surface plastic deformation of the material. Accordingly burnishing can be used for forming surface layers (SLs) of workpieces with a set of attributes - called surface integrity - which have a positive influence on the performance characteristics of products, such as: hardness, residual stresses,

\footnotetext{
* Dr hab. inż. Magdalena Szutkowska, prof. IZTW, magdalena.szutkowska@ios.krakow.pl, https://orcid.org/0000-0002-2690-8872 - Sieć Badawcza Łukasiewicz - Instytut Zaawansowanych Technologii Wytwarzania, Kraków, Polska

Dr inż. Daniel Toboła, daniel.tobola@ios.krakow.pl, https://orcid.org/0000-0001-7966-240X - Sieć Badawcza Łukasiewicz - Instytut Zaawansowanych Technologii Wytwarzania, Kraków, Polska

Prof. dr hab. inż. Lucyna Jaworska, lucyna.jaworska@ios.krakow.pl, https://orcid.org/0000-0002-1240-2694 - Sieć Badawcza Łukasiewicz - Instytut Zaawansowanych Technologii Wytwarzania, Kraków, Polska

Dr inż. Marcin Rozmus, marcin.rozmus@ios.krakow.pl, https://orcid.org/0000-0002-2236-5663 - Sieć Badawcza Łukasiewicz - Instytut Zaawansowanych Technologii Wytwarzania, Kraków, Polska
} 
microstructure and finally surface roughness. Slide burnishing is used mainly as a kind of lapping for different materials and protective coatings; it results in surfaces with very low roughness $[2,3]$. Moreover, slide burnishing is also used in sequential processes, combining mechanical and thermo-chemical treatments [4-6]. During such a process, the rounded tip of the tool is simultaneously pressed against and sliding on the surface of the workpiece, causing plastic deformation of the tops of irregularities and smoothing the surface [7]. In order to develop further applications of slide burnishing, novel ceramic composite materials have been prepared for the end tips of burnishing tool. Tests were carried out on the AISI 4140 alloy steel. Composite matrix $M A X \mathrm{Ti}_{3} \mathrm{GeC}_{2}$ and $\mathrm{TiB}_{2}$ phases were used for bonding with the diamond (Fig. 1) [8,9].

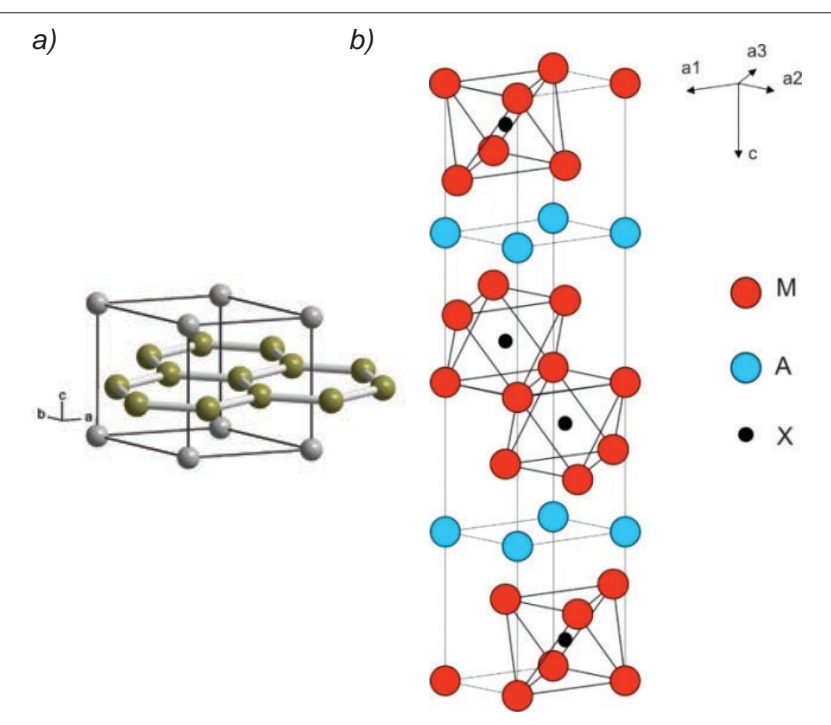

Fig. 1. Scheme of the crystal structure: a) $\left.\mathrm{TiB}_{2}, b\right) \mathrm{MAX}$-phase, where $M$ are titanium atoms, $A$ germanium atoms and $X$ carbon atoms

It is anticipated that these layered ternary carbides and nitrides will fulfil our expectations because they combine some of the best properties of ceramics and metals. MAX phases are nano-layered ceramics with the general formula $\mathrm{M}_{n+1} \mathrm{AX}_{n}(n=1 \div 3)$, where $\mathrm{M}$ is an early transition metal, $A$ is an A-group element, (mostly group III A or IV A) and $X$ is either carbon and/or nitrogen [10-12]. A list shows that there are more than $50 \mathrm{M}_{2} \mathrm{AX}$, or 211 compounds, six $M_{3} A X_{2}$ or 312 compounds [11]. These ternary compounds are hexagonal with c/a ratios in the range of $3 \div 6$. In the 312 compounds the c-axis stacking sequence includes double layers of distorted edge sharing $\mathrm{Ti}_{6} \mathrm{C}$ octahedra, reminiscent of the $\mathrm{TiC}$ structure. The double layers are separated by sheets of hexagonal nets of the A-group element. In case of the 413 compounds there are three A-group element layers separated [12-14]. This layered structure of the MAX phases gives rise to an unique set of physical properties, including unexpected combination of metallic and ceramic properties. These properties that can be attributed to the mostly metallic, with covalent and ionic contributions, of the very strong $\mathrm{M}-\mathrm{X}$ bond, together with $\mathrm{M}-\mathrm{A}$ bonds that are relatively weak, especially in shear. Like metals, they are good electrical and thermal conductors, readily machinable, tolerant to damage, and resistant to thermal shocks. Similar to ceramics, they are refractory (their decomposition temperature is higher than $2000^{\circ} \mathrm{C}$ ), oxidation resistant, quite stiff and relatively light $\left(4.5 \mathrm{~g} / \mathrm{cm}^{3}\right)$. These materials are all remarkably damage tolerant. Barsoum and Raghy explain these phenomena taking as an example fracture of a $\mathrm{Ti}_{3} \mathrm{SiC}_{2}$ sample [14]. During fracture bundles of ligaments form in the spreading crack. Any cracks that start to separate the layers bump into the kink boundaries and are stopped. The fundamental and crucial difference between the kink bands that form in the MAX phases and those in other materials is that, even after the initiation of damage, the ternary phases can still carry substantial loads. The unique combination of these interesting properties makes these ceramics promising materials for diverse and wide range of applications. The diamond-ceramic composites are possibly used as high temperature abrasive materials because they do not form liquid phases at high temperatures. As a result of minimizing the difference of thermal expansion between diamond and matrix ceramic phase, lower internal-strain bodies are expected [15]. Titanium diboride has been considered as a matrix phase, because $\mathrm{TiB}_{2}$ is known as a hard material (Vickers hardness $25 \div 35 \mathrm{GPa}$ ) with excellent resistance to mechanical erosion and strong mixed bonding consisting of ionic, metallic and covalent bonds [16]. The existence of the covalent bonding is the reason for low ductility, high hardness and high melting point of $\mathrm{TiB}_{2}$. Examinations of burnishing tool with new diamond matrix composites used for improving the surface quality of the AISI 4140 alloy steel is a purpose of this work.

\section{Materials and methods}

Diamond powder the commercially available synthetic (Element Six MDA 36, 3 $\div 6 \mu \mathrm{m}$ grade) and $\mathrm{TiB}_{2}$ nanosized powder (American Elements firm) with size of crystallites about $100 \mathrm{~nm}$ were the starting materials applied for diamond burnishers with working parts of spherical shapes. Direct synthesis (SHS) was used for producing the MAX phases from titanium, germanium (AEE, USA) and graphite (Merck, Germany). The proportions of elemental constituents in the mixes for the MAX phases were dictated by their stoichiometry. The mixes were homogenized during 24 hours by mixing with isopropyl alcohol and then dried. The powders were compacted in a steel die and processed by relatively inexpensive Self Propagating High Temperature Synthesis, SHS, a technique developed at the College of Materials Science and Ceramics of the AGH University of Science and Technology. The resulting SHS products were crushed in an Abbich mortar to powders with a grain size of $0.5 \mathrm{~mm}$ and next milled for 20 hours in a rotary-vibratory mill with WC grinding media in anhydrous isopropyl alcohol to a finer powder. The grain size distribution and average size of particles were measured using a Shimadzu (type SA-CP3) apparatus. Densities of powder and compacts were measured using a helium picnometer AccPyc 1340 from Micrometrics Inc. MAX phase powder, 10 wt. $\% \mathrm{Ti}_{3} \mathrm{GeC}_{2}$ or commercial powder, 10 wt. $\% \mathrm{TiB}_{2 \text { nano }}$, was mixed with the diamond powder and pressed at $90 \mathrm{MPa}$ into cylindrical shapes of $15 \mathrm{~mm}$ diameter and about $4 \mathrm{~mm}$ thickness. The compacts were sintered at the high pressure of $8 \pm 0.5 \mathrm{GPa}$ and high temperature of $2230 \pm 50 \mathrm{~K}$ in a Bridgman type toroidal apparatus for $30 \mathrm{~s}$ (Fig. 2). The sintering temperature was chosen so as to obtain crack-free samples with the highest values of density and sufficient mechanical properties.

After sintering, specimens were lapped on a cast iron disk, ground with DIA-Pro type diamond abrasive and polished with an OP-S type diamond abrasive. XRD measurements were taken using a PANAlytical Empyrean system with $\mathrm{Cu} \mathrm{Ka}$ radiation. Phase compositions sintered compacts were identified using the database of 
International Centre for Diffraction Data. The quantitative compositions of the diamond- $\mathrm{Ti}_{3} \mathrm{GeC}_{2}$ and $\mathrm{TiB}_{2 \text { nano }}$ composites were determined by the Rietveld method with X'Pert Plus program. Microstructural observations were made on JSM - 6440LV JEOL scanning electron microscope. Young's modulus $E$, with an accuracy of $2 \%$, and Poisson's ratio were determined by the ultrasonic method, from the velocity of propagation of transverse and longitudinal waves transmitted through the samples using a Panametrics Epoch III ultrasonic flaw detector, connected to a controlling computer.

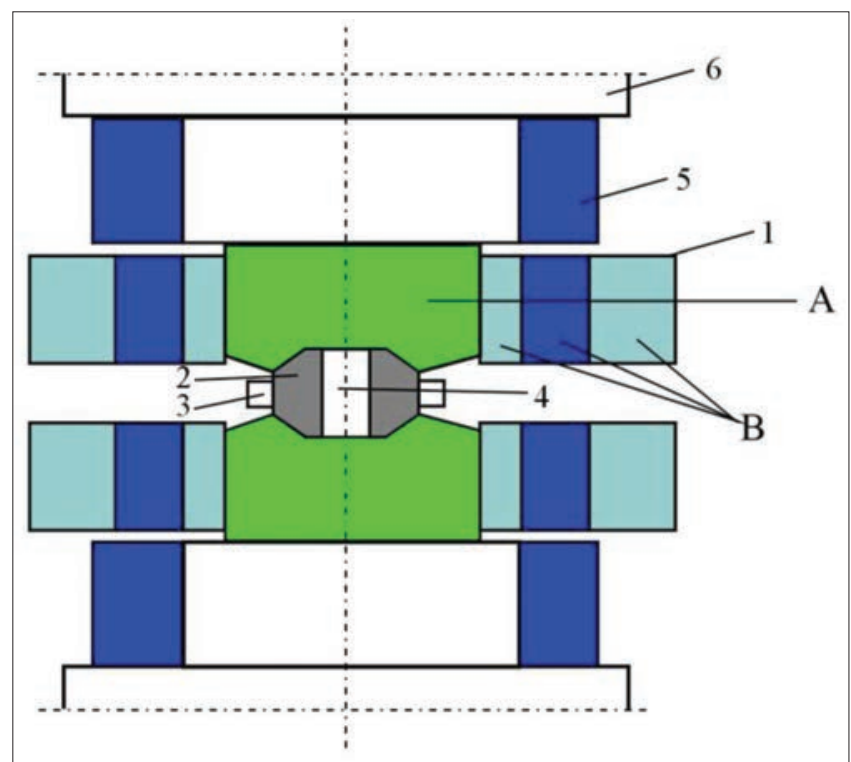

Fig. 2. Bridgman type apparatus: 1 - cell pressure $(A-$ carbide anvil, $B$ - set of steel rings), 2 - pyrophyllite gasket, 3 - pyrophyllite ring, 4 - assembly for sintering, 5 - carbide backing block, 6 - bottom platen

Apparent density $\rho$ of the sintered composite samples was determined by saturation in vacuum according to PN-EN 1389:2005 [17]. Vickers hardness was measured at a load of $9.81 \mathrm{~N}$ on three specimens each on a digital microhardness Future-Tech type FM7 instrument according to the Polish Standard PN-EN 843-4:2007 [18]. Dynamic friction values in sliding contact with a $100 \mathrm{Cr} 6$ bearing steel were determined in ball-on-disk tests, using a CETR UMT-2MT universal mechanical tester (USA). The loading mechanism applied a controlled load $F_{\mathrm{n}}$ to the ball holder and the friction force $F_{t}$ was measured continuously during the test. Fracture toughness was assessed by the conventional method (3PB) on SENB (Single Edge Notched Beam) specimens, EDM cut from the disks $[19,20]$. An initial notch $0.9 \mathrm{~mm}$ deep was produced by a diamond saw (thickness $0.20 \mathrm{~mm}$ ) and then the notch tip was pre-cracked with a thin diamond saw (thickness $0.025 \mathrm{~mm}$ ). The total initial notch length was approximately $1.1 \mathrm{~mm}$. Tensile strength was measured by the compression along the diameter of disks of $13.5 \mathrm{~mm}$ diameter, $4.0 \mathrm{~mm}$ in thickness and $0.02 \mathrm{~mm}$ flatness.

Slide burnishing was carried out using diamond tool (Fig. 3), designed and developed at the Institute of Advanced Manufacturing Technology (IAMT). The end tips of the burnishing tool had a radius $R=1.5 \mathrm{~mm}$ and were made from two diamond matrix composites - respectively containing diamond grains with $\mathrm{MAX} \mathrm{Ti}_{3} \mathrm{GeC}_{2}$ or $\mathrm{TiB}_{2}$ bonding phases. On the other hand, the burnishing was performed on a commercially available AISI 4140 alloy steel which is often used in practical applications in a quenched and tempered condition. The final microhard- ness after heat treatment was $51 \pm 1 \mathrm{HRC}$. The nominal chemical composition of the steel is presented in Table I.

The experiments were carried out on a Mori Seiki NL2000SY CNC turning-milling center, numerically controlled. The burnishing tool was fixed to the cutting head by a special fixture which ensured elastic clamping. The clamping force was recorded, along with roughness, some amplitude parameters, the type of lubricant and the burnishing speed. Longitudinal turning of the AISI 4140 alloy steel bar was first performed using a constant cutting speed $v_{\mathrm{c}}=200 \mathrm{~m} / \mathrm{min}$ as well as feed $f=0.17 \mathrm{~mm} / \mathrm{rev}$. and finally cutting depth $a_{\mathrm{p}}=0.2 \mathrm{~mm}$. An oil mist of Castrol Hysol oil was applied during burnishing. The following parameters for the burnishing process with one pass were used: speed $v=40 \mathrm{~m} / \mathrm{min}$, force $F=100 \mathrm{~N}$ and feed in the range $f=0.02 \div 0.06 \mathrm{~mm} / \mathrm{rev}$. Profilograms of the surface roughness were recorded and $R a$, the arithmetical mean deviation of the assessed profile, $R z$, the ten-point height of the profile, $R m r$, the relative material ratio (defined as a useful parameter characterizing the surface geometrical structure) and the index of the roughness change, $K_{\mathrm{Ra}}=R a^{\prime} / R a$, where $R a^{\prime}$ is the value before burnishing and $R a$ afterwards.

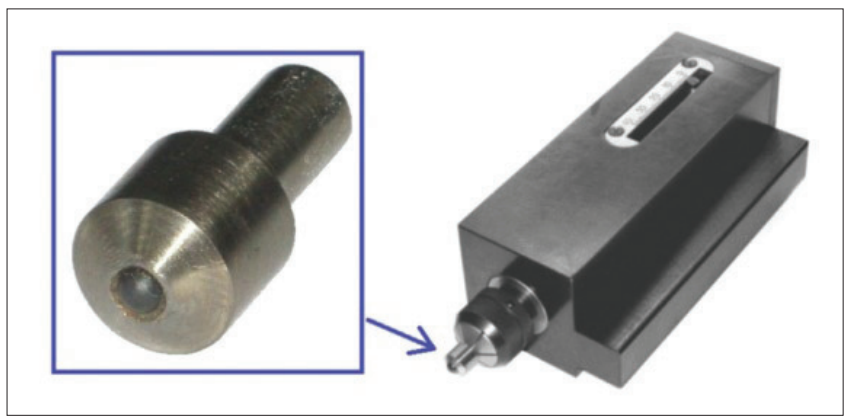

Fig. 3. Burnishing tool with tool holder and working part (pasted diamond matrix composite of spherical shape)

TABLE I. Chemical composition of the AISI 4140 alloy steel (wt.\%)

\begin{tabular}{|c|c|}
\hline $\mathrm{C}$ & $0.38 \div 0.4$ \\
\hline $\mathrm{Mn}$ & $0.75 \div 1.00$ \\
\hline $\mathrm{P}$ & 0.035 \\
\hline $\mathrm{S}$ & 0.040 \\
\hline $\mathrm{Si}$ & $0.15 \div 0.35$ \\
\hline $\mathrm{Cr}$ & $0.8 \div 1.10$ \\
\hline $\mathrm{Mo}$ & $0.15 \div 0.251$ \\
\hline
\end{tabular}

\section{Results}

HP-HT sintered Ti-Ge-C composite specimens contain 87.1 wt. $\%$ diamond, 2.8 wt. $\%$ Ge, 6.9 wt. \% graphite, 3.2 wt. $\%$ TiC while content of $\mathrm{TiB}_{2 \text { nano }}$ composite samples was 88.0 wt. $\%$ diamond, 7.6 wt. $\% \mathrm{TiB}_{2}$ and $4.5 \mathrm{wt} . \%$ graphite have shown results of $\mathrm{X}$-ray diffraction analysis - see Fig. 4. In the first case, lack of the $\mathrm{Ti}_{3} \mathrm{GeC}_{2}$ phase indicates their decomposition during the HP-HT sintering process. Therefore, SEM microstructural observations were carried out to confirmed these results - see Fig. 5. Good consolidation without microcracks and appropriate penetration of the bonding phase between diamond crystallites for both materials should also be noted.

Selected mechanical and physical properties of diamond composites with 10 wt. $\%$ of $\mathrm{Ti}_{3} \mathrm{GeC}_{2}$ and 10 wt. $\% \mathrm{TiB}_{2 \text { nano }}$ bonding phase are given in Fig. 6. Comparison of Young's modulus and tensile strength revealed respectively $14 \%$ 


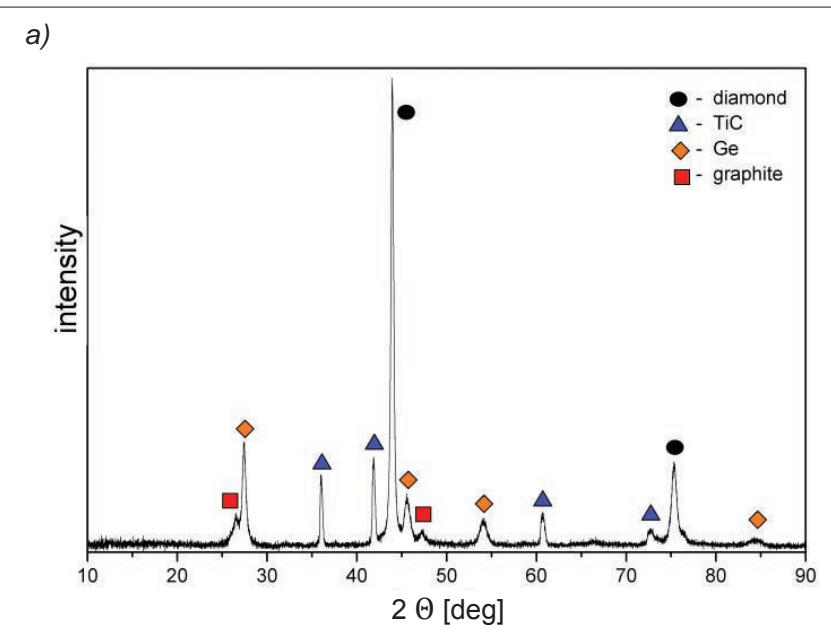

b)

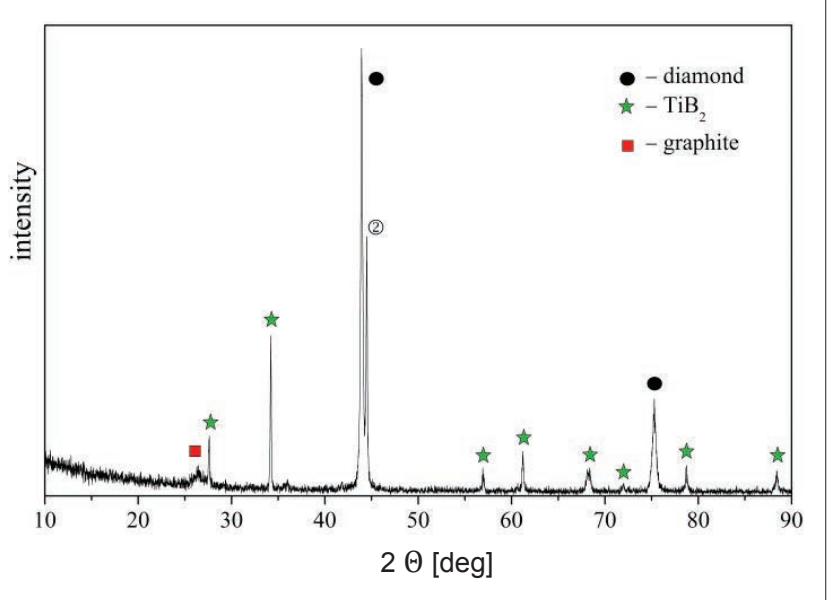

Fig. 4. X-ray diffraction of the composites: a) $\mathrm{Ti}_{3} \mathrm{GeC}_{2}$, b) $\mathrm{DTiB}_{2 \text { nano }}$
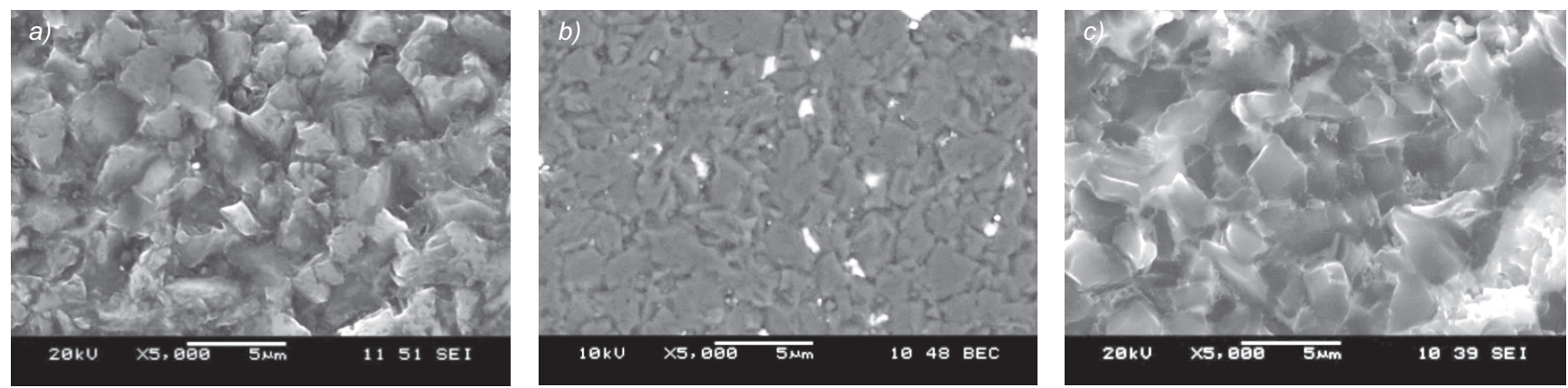

Fig. 5. SEM microstructure of the diamond composites: $a-b) \mathrm{DTiB}_{2 \text { nano }}$ (diamond - grey color, $\mathrm{TiB}_{2 \text { nano }}-$ white color), $c$ ) $\mathrm{DTi}_{3} \mathrm{GeC}_{2}$

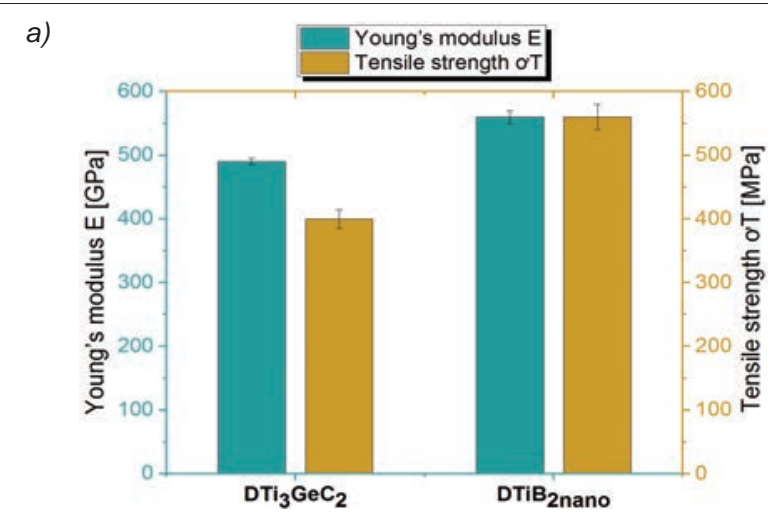

b)

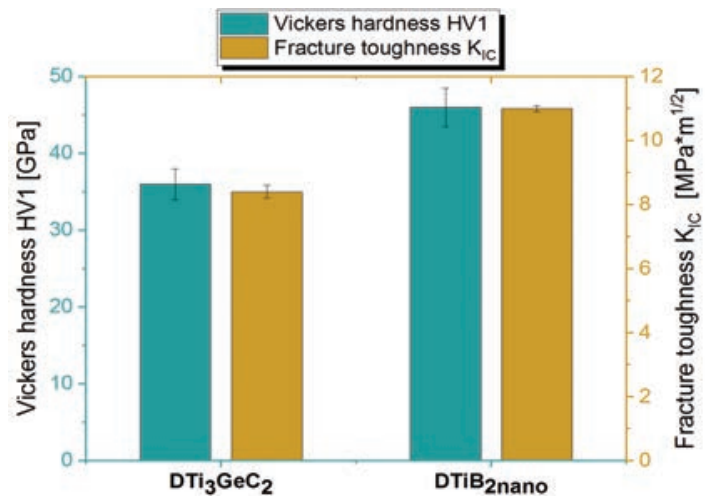

c)

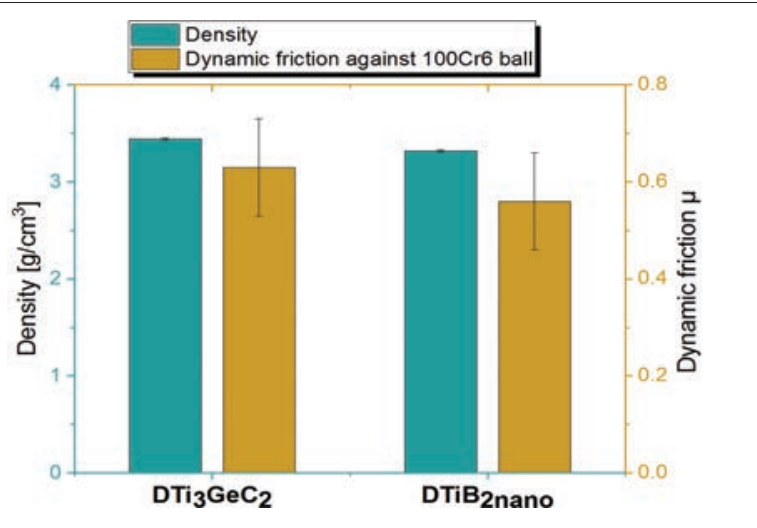

Fig. 6. Values of mechanical and physical properties of $\mathrm{DTi}_{3} \mathrm{GeC}_{2}$ and $\mathrm{DTiB}_{2 \text { nano }}$ composites: a) Young's modulus and tensile strength, $b$ ) Vickers hardness and fracture toughness, $c$ ) density and dynamic friction against $100 \mathrm{Cr} 6$ ball

and $40 \%$ higher values for samples with $\mathrm{TiB}_{2 \text { nano }}$ phase. Furthermore, higher values of hardness and fracture toughness were also determined for diamond composites with $\mathrm{TiB}_{2 \text { nano }}$ phase, respectively by $27 \%$ and $30 \%$. Meanwhile, slightly higher density has been achieved for diamond composites with 10 wt. $\%$ of $\mathrm{Ti}_{3} \mathrm{GeC}_{2}$. Finally, samples with $\mathrm{TiB}_{2 \text { nano }}$ phase are characterized by lower values of dynamic friction, more than $10 \%$.

Table II shows surface geometrical structure (SGS) values measured after turning and slide burnishing applied two diamond composite materials. Moreover, the calculated $K_{\mathrm{Ra}}$ index has been included. The Ra parameter (arithmetical mean height) of the surface after turning, but before burnishing, was between $0.35 \div 0.47 \mu \mathrm{m}$. In general, application of the burnishing tool with both materials as 


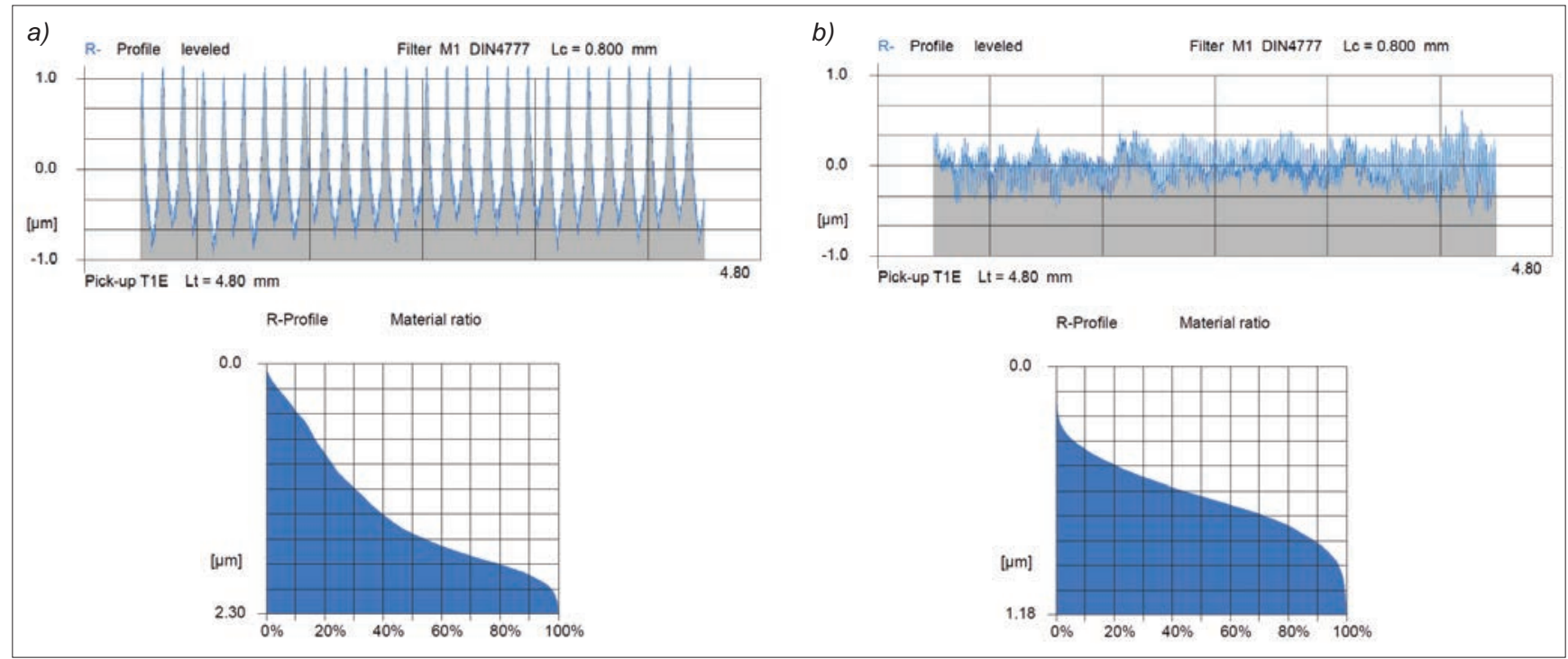

Fig. 7. Examples of the profilograms and material ratio for the specimen surface after: a) turning, $b)$ turning + burnishing $\left(\mathrm{DTiB}_{2 \text { nano }}, f=0.02 \mathrm{~mm} / \mathrm{rev}\right.$.

TABLE II. Results of SGS measurements for AISI 4140 alloy steel, after turning and slide burnishing with constant force $F=100 \mathrm{~N}$, applied two examined working parts

\begin{tabular}{|c|c|c|c|c|c|c|c|c|c|c|c|c|}
\hline \multirow[b]{2}{*}{$\begin{array}{l}\text { Burnishing tool } \\
\text { working } \\
\text { part }\end{array}$} & \multicolumn{5}{|c|}{ SGS parameters after turning } & \multirow[b]{2}{*}{$f[\mathrm{~mm} / \mathrm{rev}]}$. & \multicolumn{5}{|c|}{ SGS parameters after burnishing } & \multirow[b]{2}{*}{$K_{\mathrm{Ra}}$} \\
\hline & $R a^{\prime}[\mu \mathrm{m}]$ & $R z^{\prime}[\mu \mathrm{m}]$ & $R p^{\prime}[\mu \mathrm{m}]$ & $R t^{\prime}[\mu \mathrm{m}]$ & $\begin{array}{c}c^{\prime}, \% R t^{\prime} \\
\text { for } \\
R m r^{\prime}(c)=50 \%\end{array}$ & & $R a[\mu \mathrm{m}]$ & $R z[\mu \mathrm{m}]$ & $R p[\mu \mathrm{m}]$ & $R t[\mu \mathrm{m}]$ & $\begin{array}{c}c, \% R t \\
\text { for } \\
R m r(c)=50 \%\end{array}$ & \\
\hline \multirow{3}{*}{$\mathrm{DTi}_{3} \mathrm{GeC}_{2}$} & 0.35 & 1.88 & 0.88 & 1.96 & 0.8 & 0.02 & 0.24 & 1.86 & 0.92 & 2.14 & 0.9 & 1.5 \\
\hline & 0.40 & 2.89 & 2.38 & 3.66 & 2.4 & 0.04 & 0.31 & 1.81 & 1.06 & 2.00 & 1.0 & 1.3 \\
\hline & 0.36 & 1.97 & 1.24 & 2.16 & 1.2 & 0.06 & 0.33 & 2.27 & 1.08 & 2.46 & 1.1 & 1.1 \\
\hline \multirow{3}{*}{$\mathrm{DTiB}_{2 \text { nano }}$} & 0.41 & 2.13 & 1.12 & 2.24 & 1.1 & 0.02 & 0.15 & 1.18 & 0.54 & 1.38 & 0.5 & 2.7 \\
\hline & 0.47 & 2.50 & 1.24 & 2.72 & 1.2 & 0.04 & 0.33 & 2.56 & 1.04 & 2.76 & 0.9 & 1.4 \\
\hline & 0.37 & 2.40 & 1.40 & 2.48 & 1.4 & 0.06 & 0.43 & 3.25 & 1.22 & 3.38 & 1.1 & 0.9 \\
\hline
\end{tabular}

a)

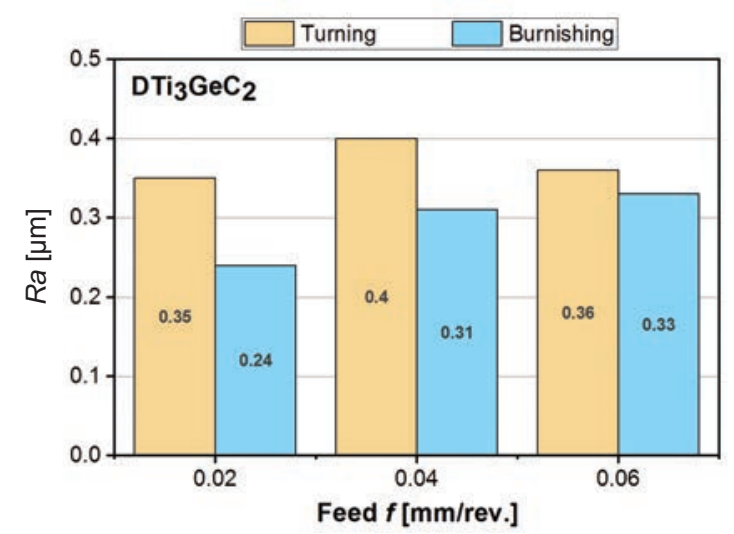

c)

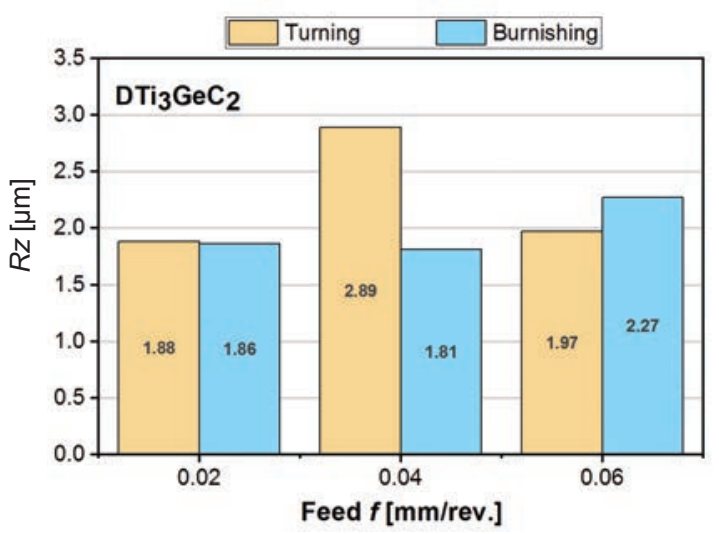

b)

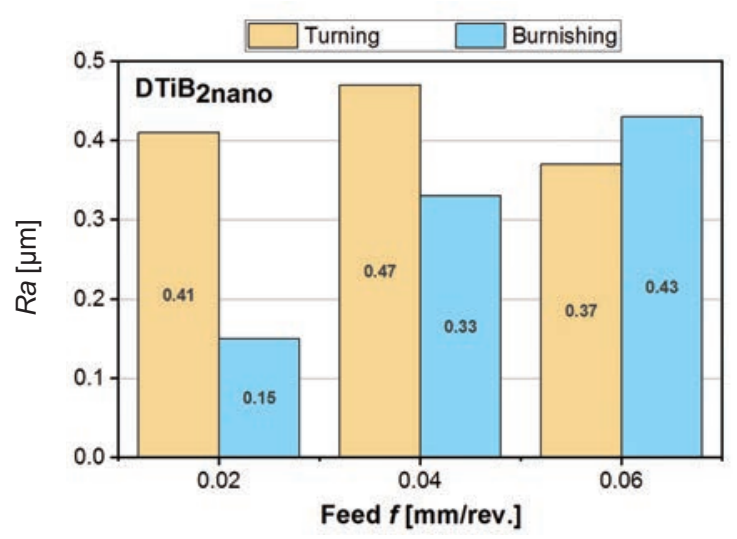

d)

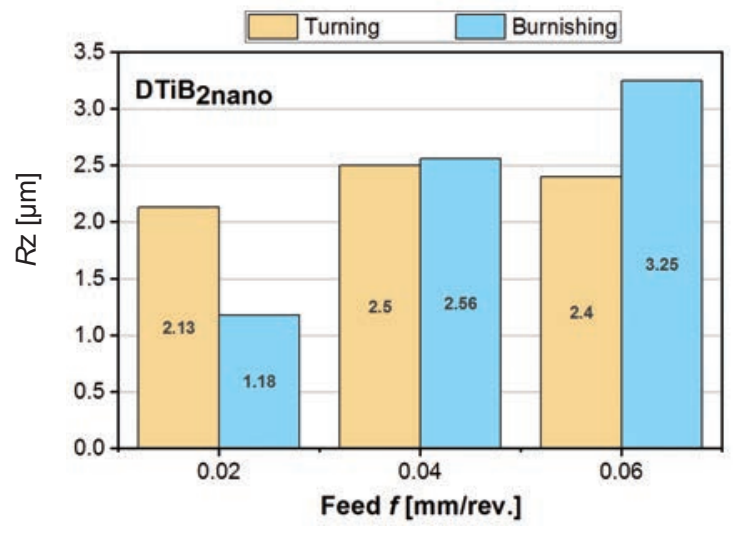

Fig. 8. Selected roughness parameters $(R a, R z)$ for AISI 4140 alloy steel surface after turning (constant $f=0.17 \mathrm{~mm} / \mathrm{rev}$.) and after slide burnishing with variable feed used two types of diamond matrix composite tools: $\mathrm{DTi}_{3} \mathrm{GeC}_{2}(a, c)$ and $\mathrm{DTiB}_{2 \text { nano }}(b, d)$ 


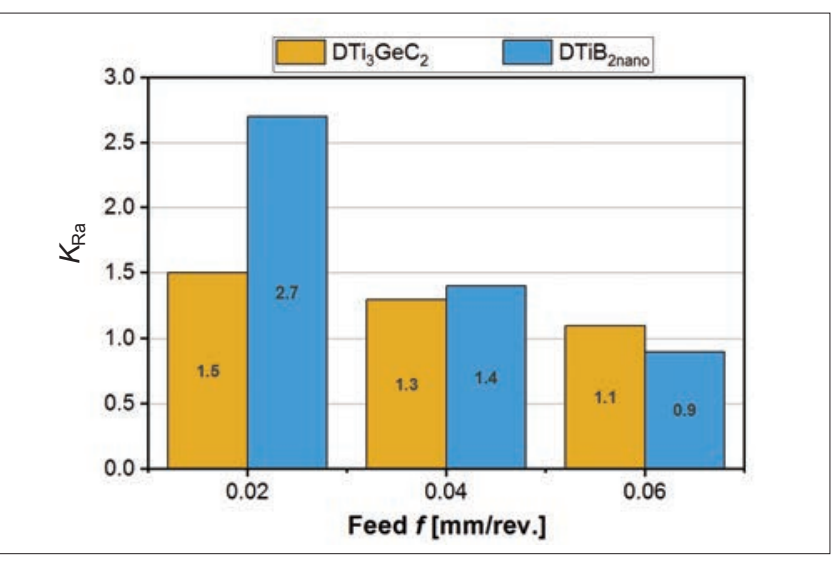

Fig. 9. Values of the $K_{\mathrm{Ra}}$ index of the roughness change after slide bur nishing with variable feed used two types of diamond matrix composite tools: $\mathrm{DTi}_{3} \mathrm{GeC}_{2}$ and $\mathrm{DTiB}_{2 \text { nano }}$

a working part causes a reduction of values in relation to the initial roughness. Examples of the profile after turning and also slide burnishing used diamond composite with 10 wt. $\% \mathrm{TiB}_{2 \text { nano }}$ bonding phase $(f=0.02 \mathrm{~mm} / \mathrm{rev}$.) are shown in Fig. 7. In this case, after burnishing we observed a reduction, by more than a factor of two, of the parameter c \%, namely $R t$ for $R m r(c)=50 \%$. The material ratio increases at the same time. Thus the area of tool/workpiece contact increases substantially.

Figure 8 shows the results of $R a$ and $R z$ parameters obtained for the AISI 4140 alloy steel surface after turning and slide burnishing processes with working parts made of the two composite materials. The lowest values of SGS have been achieved for the $\mathrm{DTiB}_{2 \text { nano }}$ composite using a feed $f=0.02 \mathrm{~mm} / \mathrm{rev}$. Similar situation takes place in the case of $K_{\mathrm{Ra}}$ index values of the roughness change (Fig. 9), what prove a better improvement in the AISI 4140 alloy steel surface smoothness due to slide burnishing with working parts made from $\mathrm{DTiB}_{2 \text { nano }}$ composites.

\section{Conclusions}

The effect of slide burnishing process using two types of diamond composites with various ceramic bonding phases as a working part on the surface state of AISI 4140 alloy steel was analyzed. Moreover, selected mechanical and physical properties of investigated diamond composites were determined. Based on the results achieved during studies, the following conclusions are derived:

- Comparison of $\mathrm{TiB}_{2 \text { nano }}$ diamond composite with samples based on the $\mathrm{Ti}_{3} \mathrm{GeC}_{2}$ phase revealed the predominance of the former.

- Determined for $\mathrm{TiB}_{2 \text { nano }}$ diamond composite mechanical properties such as hardness, Young's modulus, fracture toughness and finally tensile strength were respectively higher by $27 \%, 14 \%, 30 \%$ and $40 \%$ compared to $\mathrm{Ti}_{3} \mathrm{GeC}_{2}$ diamond composite.

- More than $10 \%$ lower values of dynamic friction were also obtained for $\mathrm{TiB}_{2 \text { nano }}$ diamond composite.

- On the other hand, $\mathrm{Ti}_{3} \mathrm{GeC}_{2}$ diamond composite has been achieved slightly higher density.

- In the case of surface roughness parameters ( $R a, R z$, $R p, R t$ ) of AISI 4140 alloy steel after slide burnishing with TiB2nano diamond composite, a significant reduction is observed. This is indicated by the $K_{\mathrm{Ra}}$ index with the value of 2.7 .

An increase in the material ratio was achieved (by more than a factor of two), which substantially increases the area of workpiece contact. It should be also noted that the total contact area is a function of load and penetration hardness of the softer material.

\section{Acknowledgments}

This research was supported by the COST Action CA15102 - "Solutions for Critical Raw Materials Under Extreme Conditions" (CRM-EXTREME) and financed from the Institute statutory activities.

\section{REFERENCES}

[1] Żak K., Grzesik W., Prażmowski M. "Investigation of sequential cryogenic hard turning and ball burnishing processes". Metalurgija. 53 (2014): 521-525.

[2] Brostow W., Czechowski K., Polowski W., Rusek P., Wronska I. "Slide diamond burnishing of tool steels with adhesive coatings and diffusion layers". Material Research Innovations. 17 (2013): 269-277.

[3] Okada M., Shinya M., Matsubara H., Kozuka H., Tachiya H., Asakawa N., Otsu M. "Development and characterization of diamond tip burnishing with a rotary tool". Journal of Materials Processing Technology. 244 (2017): 106-115.

[4] Toboła D., Brostow W., Czechowski K., Rusek P., Wronska I. "Structure and properties of burnished and nitrided AISI D2 tool steel". Material Science (Medziagotyra). 21 (2015): 511-516.

[5] Toboła D., Brostow W., Czechowski K., Rusek P. "Improvement of wear resistance of some cold working tool steels". Wear. 382-383 (2017): 29-39.

[6] Toboła D., Kania B. "Phase composition and stress state in the surface layers of burnished and gas nitrided Sverker 21 and Vanadis 6 tool steels". Surface and Coatings Technology. 353 (2018): $105-115$.

[7] Korzynski M., Zarski T. "Slide diamond burnishing influence on of surface stereometric structure of an AZ91 alloy". Surface and Coatings Technology. 307 (2016): 590-595.

[8] Xiang H., Feng Z., Li Z., Zhou Y. "Temperature-dependence of structural and mechanical properties of $\mathrm{TiB}_{2}$ : A first principle investigation". Journal of Applied Physics. 117 (2015): 225902-1-225902-8.

[9] Magnuson M., Palmquist J.-P., Mattesini M., Li S., Ahuja R., Eriksson O., Emmerlich J., Wilhelmsson O., Eklund P., Högberg H., Hultman L., Jansson U. "Electronic structure investigation of $\mathrm{Ti}_{3} \mathrm{AlC}_{2}$, $\mathrm{Ti}_{3} \mathrm{SiC}_{2}$, and $\mathrm{Ti}_{3} \mathrm{GeC}_{2}$ by soft X-ray emission spectroscopy". Physics Letters. B 72 (2005): 1-15.

[10] Low I.-M., Zhou Y. "MAX Phases: Microstructure, Properties and Applications". New York: Nova Science Publishers Inc., 2012, 1-282.

[11] Riedel R., Chen I.-W. "Ceramics Science and Technology. Materials and Properties". WILEY-VCH Verlag GmbH\& Co. KGaA, 2010, 1-862.

[12] Low I.M. "Advances in Science and Technology of $M_{n+1} A X_{n}$ Phases". Cambridge: Woodhead Publishing Limited, 2012, 1-474.

[13] Eklund P., Beckers M., Jansson U., Högberg H., Hultman L. "The $M_{n+1} A X_{n}$ phases: Materials science and thin-film processing". Thin Solid Films. 518 (2010): 1851-1878.

[14] Barsoum M.W., El-Raghy T. "The MAX phases: Unique new carbide and nitride materials". American Scientists. 89 (2001): 334-343.

[15] Ko Y.S., Tsurumi T., Fukunada O., Yano T. "High pressure sintering of diamond-SiC composite". Journal of Materials Science. 36 (2001): 469-475.

[16] Will G. "Electron deformation density in titanium diboride chemical bonding in $\mathrm{TiB}_{2}$ ". Journal of Solid State Chemistry. 117 (2004): 628-631.

[17] Polish Standard PN-EN 1389:2005. Advanced technical ceramics. Ceramic composites. Physical properties. Determination of density and open porosity. (2005).

[18] Polish Standard PN-EN 843-4:2007, Advanced technical ceramics. Mechanical properties of monolithic ceramics at room temperature. Part 4. Surface hardness according to: Vickers, Knoop and Rockwell. (2007).

[19] Szutkowska M., Jaworska L., Boniecki M., Stobierski L., Rozmus M. "Mechanical behavior of diamond matrix composites with ceramic $\mathrm{Ti}_{3}(\mathrm{Si}, \mathrm{Ge}) \mathrm{C}_{2}$ bonding phase". International Journal of Refractory Metals and Hard Materials. 49 (2015): 302-306.

[20] Jaworska L., Szutkowska M., Morgiel J., Stobierski L., Lis J. " $\mathrm{Ti}_{3} \mathrm{SiC}_{2}$ as a bonding phase in diamond composite". Journal of Materials Science Letters. 20 (2001): 1783-1786. 